\title{
FIRST GLIMPSES OF THE ZOOLOGY OF THE NATUNA ISLANDS.
}

\section{INTRODUCTION.}

\section{BY THE HON. WALTER ROTHSCHILD.}

A BOUT a year ago, during a conversation with Mr. Hartert about unexplored islands, my attention was inadvertently drawn, at a glance on the map of the Malayan Archipelago, to the group of islands called the Natuna Islands on the maps. I became at once deeply interested in the subject, and decided to do my best to make their fauna known to the scientific world. Mr. Hartert, who shared my enthusiasm, declared himself willing to undertake the exploration of the Natunas in abont three or four years, if they should remain unexplored so long. This, however, was not their fate, for I learnt from Mr. Charles Hose, the well-known explorer of the interior of Sarawak, that he had already thought of exploring that group of islands; and I made arrangements with him that I should have the result of his investigations for my Museum. But even Mr. Hose was not destined to be the first zoologist on the Natunas, for, when he returned to Borneo, he found that true and faithful zoologist, Mr. A. Everett, so well known from his many successful explorations on the Philippines, Palawan, Borneo, and other islands, ready for a trip to the Natunas. He informed Mr. Everett of my interest in the Natunas, and the latter gentleman was willing to forward his collections to my Mnseum, where I promised him they would be studied and described.

In the following pages I offer the first list of the birds from Sirhassen and Bunguran, prepared for me by Mr. Hartert. As the collection contained animals of most classes-altogether a wonderful success, considering the short time of Mr. Everett's collecting-lists of the different groups will be given in due time, each order being worked ont by specialists, the lepidoptera only by myself. Such groups, of which the collections were too small, as the coleoptera, will be worked ont when further material comes to hand. This will, I hope, soon be the case, as Mr. C. Hose intends to visit both the Natunas and Anambas with a number of native collectors, in order to complete Mir. Everett's investigations.

The Natuna Islands* extend in a N.W. by N. $\frac{1}{2}$ N. direction to the distance of 190 miles from Tanjong Api, the N.W. cape of Borneo. They may be divided into three groups-South Natunas, nearest to Borneo ; Great Natunas, or Bunguran with its contiguous islets ; and North Natuna, or Pulu Lant.

The South Natunas, or Little Natunas, with Subi and Sirhassen, extend from the coast of Borneo to about lat. $3^{\circ} 5^{\prime} \mathrm{N}$. Marundum, the southernmost island of this group, is in lat. $2^{\circ} 4^{\prime}$ N., long. $109^{\circ} 6 \frac{1^{\prime}}{2}$ E., and only 14 miles from Tanjong Api. Subi, the northernmost and largest island of this group, is about 12 miles long and 5 miles wide, and about 63 miles from Cape Api. Between Subi and Marundum lies Sirhassen, 9 miles long. This is the only island of this group visited by Mr. Everett.

* See Findlay's Indian Archipelago Directory (London, 1889), from which most of the following notes are taken. 
The largest of the Natuna group, Great Natuna, or properly Bunguran, extends from $3^{\circ} 38 \frac{1}{2}^{\prime}$ to $4^{\circ} 16 \frac{1}{3}^{\prime} \mathrm{N}$. Cape Datto, the north extreme of the island, is in long. $108^{\circ} 11^{\prime}$ E., and Cape Senubing, the east extreme, in long. $108^{\circ} 21 \frac{1}{2}^{\prime}$ E., its breadth being about 25 miles.

This island is largely clothed with heavy forest. The interior is mostly high, and in the northern part are two mountains of considerable elevation, Mount Bedong or Quoin Hill, and Mount Ranai, the latter being 1890 feet high. The greater part of the coasts of Bunguran are fronted by reefs and islets, making the approach more or less dangerons to vessels, all the more so as they are but incompletely surveyed. Bunguran is inhabited by Malays.

The North Natunas are of moderate height, produce cocoanuts and some other fruits, and are inhabited by Malays. The smaller islands are rocky and sterile. The name "Natuna Islands," given by the Europeans to these groups, is entirely unknown to the Malays.

The following extracts from a letter of Mr. Everett I believe to be of great interest, considering the importance of the field-observer's opinion :-

"I was absent from Labuan sixty-four days, out of which I got only twenty-five working days, of which fourteen days were rainy. Although I left Labuan on September 2nd, I did not reach Bunguran until September 29th, owing to breakdown of the steamer chartered, and to foul weather encountered in the native schooner subsequently. In consequence of the shortness of the time spent on shore of the islands, and the continual storms of wind and rain ushering in the commencement of the rainy season, my collection is small, though fair enough for the number of actual working days. There is a considerable number of mammals on Bunguran. You will find among the collection a Mydaus, Semnopithecus, Galeopithecus, Tupaia, Squirrels, Rats and Bats, Tragulus. There is also a Manis which I did not get, another Tragulus, one or two small Carnivora, probably some more Rodents, and perhaps another Tupaia, which I did not procure. The Deer have been introduced from Dutch Borneo.

"I was much disappointed with the birds, which appear to differ but little from those found on the Malay Peninsula, though there may be found more peculiarity when they come to be actually compared with a series of the latter. There must be a great number of species, however, which I did not meet with, as the island is largely clothed with heavy forest. Therefore there remains plenty of work to be done.

"I did not once on the islands hear the note of a Barbet (Megalaema). The only Pitta obtained is the common P. cyanoptera. I could hear of no such bird as a pheasant or partridge. My station was at the foot of Mount Ranai (1890 feet), on which such birds would be found if they existed. Neither in the North nor in the Sonth Natunas are any Megapodes found.

"The Northern Natunas will, zoologically, have to be grouped with the Malay Peninsula, I think; the Southern seem to belong, zoologically, to Borneo. Considering how closely they approach each other and the extreme shallowness of the intervening sea, it seems remarkable that there should be a well-defined line of demarcation between the faunas of the two groups. The presence of the genera Mydaus and Manis (both of which seem to be absent from Sirhassen) on Bunguran seems to prove its continental character."

(See conclusions on p. 483.) 


\section{$2 \mathrm{BHL}$ Biodiversity Heritage Library}

1894. "First glimpses of the zoology of the Natuna Islands. I. Introduction." Novitates zoologicae : a journal of zoology in connection with the Tring Museum 1, 467-468. https://doi.org/10.5962/bhl.part.24567.

View This Item Online: https://www.biodiversitylibrary.org/item/24179

DOI: https://doi.org/10.5962/bhl.part.24567

Permalink: https://www.biodiversitylibrary.org/partpdf/24567.

\section{Holding Institution}

Natural History Museum Library, London

\section{Sponsored by}

Natural History Museum Library, London

\section{Copyright \& Reuse}

Copyright Status: Public domain. The BHL considers that this work is no longer under copyright protection.

This document was created from content at the Biodiversity Heritage Library, the world's largest open access digital library for biodiversity literature and archives. Visit BHL at https://www.biodiversitylibrary.org. 